\title{
Output Gaps and Robust Monetary Policy Rules*
}

\author{
Roberto M. Billi \\ Sveriges Riksbank
}

\begin{abstract}
Policymakers often use the output gap to guide monetary policy, even though inflation and nominal gross domestic product (NGDP) are measured more accurately in real time. Employing a small New Keynesian model with a zero lower bound (ZLB) on nominal interest rates, this article compares the performance of monetary policy rules that are robust to persistent measurement errors. It shows that, in the absence of the ZLB, the central bank should focus on stabilizing inflation rather than nominal GDP. But when the ZLB is present, a policy that seeks to stabilize nominal GDP improves substantially the tradeoffs faced by the central bank.
\end{abstract}

JEL Codes: E31, E52, E58.

*I thank for valuable comments Yunus Aksoy, Pierpaolo Benigno (coeditor), Fabio Canova, Larry Christiano, Emmanuel De Veirman, Andy Filardo, Jordi Galí, Tor Jacobson, Per Jansson, Keith Kuester, Stefano Neri, Damjan Pfajfar, Charles Plosser, Ricardo Reis, Frank Smets, Ulf Söderström, Lars Svensson, John Taylor, Robert Tetlow, David Vestin, Karl Walentin, John Williams, Mike Woodford, Andreas Wörgötter, seminar participants at Banca d'Italia, Bank of England, Copenhagen Business School, Federal Reserve Bank of Philadelphia, Joint Seminar Series of the ECB-CFS-Bundesbank, Sveriges Riksbank, Tilburg University, Uppsala University, as well as conference participants at AEA, Joint French Macro Workshop at Banque de France, Macro Workshop at De Nederlandsche Bank, Midwest Macroeconomics Meeting, Monetary Policy Challenges from a Small Country Perspective at National Bank of Slovakia, and SCE. I gratefully acknowledge the ECB's hospitality while working on this project in 2018. The views expressed herein are solely the responsibility of the author and should not be interpreted as reflecting the views of Sveriges Riksbank. Address correspondence to: Roberto M. Billi, Monetary Policy Department, Sveriges Riksbank, SE-103 37 Stockholm, Sweden; e-mail: Roberto.Billi@riksbank.se. 


\section{Introduction}

In monetary policy analysis, a commonly used measure of economic activity is the output gap, which is a gauge of how far the economy is from its productive potential. The output gap is conceptually appealing as an indicator to help guide policy because it is an important determinant of inflation developments. A positive output gap implies an overheating economy and upward pressure on inflation. By contrast, a negative output gap implies a slack economy and downward pressure on inflation. Thus, if available, accurate and timely estimates of the output gap can play a central role in the conduct of effective monetary policy. A positive output gap prompts the central bank to cool an overheating economy by raising policy rates, whereas a negative output gap prompts for adding monetary stimulus.

In practice, however, the output gap is a noisy signal of economic activity. Estimates of the output gap are often subject to large revisions, even long after the time policy is actually made 11 Thus, there is broad interest in finding monetary policies that are robust to persistent errors in measuring the output gap. As Taylor and Williams (2010) explained, one view is that in simple policy rules the optimal coefficient on the output gap declines in the presence of noise in measuring the gap. The logic for this result is straightforward. The reaction to the mismeasured output gap adds unwanted noise to the setting of monetary policy, which causes unnecessary fluctuations in output and inflation. Such adverse effects of noise can be reduced by lowering the coefficient on the output gap in the policy rule.

At the same time, many argue for greater policy activism when the zero lower bound (ZLB) on nominal interest rates constrains policy 2 The inability to reduce the policy interest rate below its

\footnotetext{
${ }^{1}$ Measuring the output gap involves two complications. First, potential output cannot be measured directly, so it must be estimated. Second, GDP data are regularly revised as statistical agencies incorporate more complete source information and new methodologies into the published data. As Orphanides and van Norden (2002) showed, estimating potential output is the main source of errors in measuring the output gap.

${ }^{2}$ This article adopts the standard practice of referring to a zero lower bound on nominal interest rates. The recent experience with negative nominal interest rates
} 
effective lower bound can limit, or even impair, the ability of monetary policy to stabilize output and inflation. As Reifschneider and Williams (2000) showed, increasing the coefficient on the output gap in simple policy rules can improve economic performance. An active response to the output gap prescribes greater monetary stimulus before and after episodes when the ZLB constrains policy, which lessens deflationary pressures when the ZLB constrains policy. But there are clear limits to such an approach, as it generally increases the volatility of inflation and interest rates. A large coefficient on the output gap can be counterproductive, especially when the output gap is mismeasured.

In light of such concerns, another perspective is that central banks should ignore the output gap altogether to focus strictly on stabilizing inflation or seek instead to stabilize the level of nominal gross domestic product (NGDP). NGDP-level targeting is particularly appealing for two reasons. First, monetary policy is then expected to be more robust to errors in the measurement of economic activity, because revisions to GDP are typically smaller than revisions to the output gap. Estimates of GDP are not prone to errors from estimating potential output. Second, the central bank is also required to make up for any past shortfalls from its NGDP target, which ensures greater policy stimulus during ZLB episodes.

This article, thus, studies the performance of such monetary policy rules in a small New Keynesian model, with the central bank facing persistent errors in the measurement of economic conditions and a ZLB constraint 3 In the model, several types of structural and noise shocks buffet the economy. On the supply side, technology shocks push output gaps and inflation in the same direction, whereas cost-push shocks instead cause an inflation-output tradeoff. On the demand side, adverse demand shocks and the ZLB constraint create a tradeoff between stabilizing current and future output, because it is desirable for the central bank in a ZLB episode to promise to

in Denmark, Japan, Sweden, Switzerland, and the euro zone suggests the effective lower bound is somewhat below zero. See Svensson (2010) for a discussion.

${ }^{3}$ This analysis assumes the private sector possesses full information about the state of the economy in real time, which implies the model can be treated as structurally invariant under different policies. See Aoki (2003, 2006) and Svensson and Woodford (2004) for a discussion. 
induce an expansion after the ZLB episode 4 Moreover, the central bank faces persistent noise shocks in the setting of monetary policy, which creates a tradeoff between fluctuations in the economy from structural shocks and those from noise shocks.

The stylized model offers a clear illustration of such tradeoffs in the evaluation of the monetary policy rules. Before proceeding to the evaluation, the model is calibrated to recent U.S. data, with the conduct of monetary policy described by a simple rule often used in policy analysis, namely a version of the Taylor rule with interest rate smoothing. In the calibration of the model, the structural shocks are persistent to generate propagation in the model as in the data. The noise shocks are persistent to reflect historical revisions of the data. Also considered is the optimal commitment policy, to be used as a benchmark for the evaluation. The monetary policy rules are then ranked in terms of performance, based on the model's social welfare function.

With the calibrated model, I study the extent to which persistent errors in the measurement of economic conditions and a ZLB constraint adversely affect the performance of the two targeting rules and inertial Taylor rule, relative to the optimal commitment policy. The analysis produces three main results. First, under the optimal commitment policy, although measurement error and the ZLB constraint are both a source of fluctuations in output and inflation, social welfare is more severely affected by the ZLB constraint. As a second main result, the ZLB constraint plays a critical role for the ranking of two targeting rules. In the absence of the ZLB, the central bank should focus on stabilizing inflation rather than nominal GDP. But present the ZLB, a policy that seeks to stabilize the level of nominal GDP improves substantially the tradeoffs faced by the central bank. And third, if monetary policy becomes more severely constrained by the ZLB, social welfare is more severely affected under a targeting rule that does not require the central bank to make up for past shortfalls from the target.

In the previous literature, in the aftermath of the financial crisis and Great Recession, proposals for NGDP-level targeting include

\footnotetext{
${ }^{4}$ The promise is credible if the central bank commits to making up for past shortfalls from its target, as is the case with an inertial Taylor rule or with a NGDP-level target.
} 
Hatzius and Stehn (2011, 2013), Sumner (2011, 2014), Woodford (2012, 2013), Frankel (2013), and Billi (2017), among others 5 But none of these articles takes into account that central banks face persistent errors in the measurement of economic conditions. In another strand of literature, studies about the design of monetary policies that are robust to measurement error include Orphanides et al. (2000), Orphanides (2001, 2003), Rudebusch (2002), Smets (2002), Aoki (2003, 2006), Ehrmann and Smets (2003), Svensson and Woodford (2003, 2004), Boehm and House (2014), Garín, Lester, and Sims (2016), and others. But these articles do not take into account a ZLB constraint. Gust, Johannsen, and López-Salido (2017) study the interaction between mismeasurement of the state of the economy and a ZLB constraint but for tractability need to assume the mismeasurement is not persistent. Relative to the previous literature, the contribution of this article is to show that the ranking of the monetary policy rules depends crucially on the likelihood of hitting the ZLB constraint.

The article proceeds as follows. Section 2 describes the model and monetary policy rules. Section 3 presents the model outcomes and policy evaluation. Section 4 concludes. The appendix contains technical details of the model solution and additional results.

\section{The Model}

I use a small New Keynesian model as described in Woodford (2010). I describe the conduct of monetary policy with targeting rules, and with a simple rule to be used for the calibration of the model. In each of the policy frameworks considered, the central bank faces persistent errors in the measurement of economic conditions and a ZLB constraint. I explain the features of this model and the equilibrium, and then calibrate the model to U.S. data.

\footnotetext{
${ }^{5}$ There is also an extensive literature on the notion of nominal income growth targeting, at first suggested by Meade (1978) and Tobin (1980) and then studied by Bean (1983), Taylor (1985), West (1986), McCallum (1988), Clark (1994), Hall and Mankiw (1994), Jensen (2002), Walsh (2003), and Billi (2011b), among others.
} 


\subsection{Private Sector}

The behavior of the private sector is described by two structural equations, log-linearized around zero inflation, which represent the demand and supply sides of the economy. The economy is buffeted by persistent demand and supply shocks.

On the demand side of the economy, the Euler equation describes the representative household's expenditure decisions,

$$
y_{t}=E_{t} y_{t+1}-\varphi\left(i_{t}-r-E_{t} \pi_{t+1}-v_{t}\right),
$$

where $E_{t}$ denotes the expectations operator conditional on information available at time $t . y_{t}$ is output measured as the log-deviation from a trend. $\pi_{t}$ is the inflation rate, the log-change of prices from the previous period,

$$
\pi_{t} \equiv p_{t}-p_{t-1}
$$

And $i_{t} \geq 0$ is the short-term nominal interest rate, which is the instrument of monetary policy and is constrained by a ZLB. $r>0$ is the steady-state interest rate $6 \varphi 0$ is the interest elasticity of real aggregate demand, capturing intertemporal substitution in household spending. The demand shock, $v_{t}$, represents other spending, such as government spending, which has asymmetric effects on the economy due to the ZLB constraint. A positive demand shock can be countered entirely by raising the nominal interest rate, whereas a large adverse shock that leads to hitting the ZLB causes an economic downturn.

On the supply side of the economy, the Phillips curve describes the optimal price-setting behavior of firms, under staggered price changes à la Calvo,

$$
\pi_{t}=\beta E_{t} \pi_{t+1}+\kappa x_{t}+u_{t},
$$

where $\beta \in(0,1)$ is the discount factor of the representative household, determined as $1 /(1+r)$. The slope parameter $\kappa>0$ is a function of the structure of the economy $x_{t} \equiv y_{t}-y_{t}^{n}$ is the output gap

\footnotetext{
${ }^{6}$ Thus, $i_{t}-r-E_{t} \pi_{t+1}$ is the real interest rate in deviation from steady state.

${ }^{7}$ In this model $\kappa=(1-\alpha)(1-\alpha \beta) \alpha^{-1}\left(\varphi^{-1}+\omega\right)(1+\omega \theta)^{-1}$, where $\omega>0$ denotes the elasticity of a firm's real marginal cost. $\theta>1$ is the price elasticity of demand substitution with firms in monopolistic competition, and thus the
} 
in the economy. $y_{t}^{n}$ is the natural rate of output, or potential output, the output deviation from the trend that would prevail in the absence of any price rigidities, which represents a technology shock. A positive technology shock implies slack in economic activity and downward pressure on prices, whereas a negative shock implies a strong economy and puts upward pressure on prices. Moreover, $u_{t}$ is a cost-push shock, or markup shock resulting from variation over time in the degree of monopolistic competition between firms, which creates an inflation-output tradeoff for monetary policy.

In this model economy, the three types of exogenous structural shocks $\left(y_{t}^{n}, u_{t}, v_{t}\right)$ are assumed to follow $\mathrm{AR}(1)$ stochastic processes, with first-order autocorrelation parameters $\rho_{j} \in[0,1)$ for $j=y^{n}, u, v$. Moreover, $\sigma_{\varepsilon j} \varepsilon_{j t}$ are the innovations that buffet the economy, which are independent across time and cross-sectionally, and are normally distributed with mean zero and standard deviations $\sigma_{\varepsilon j}>0$.

Finally, the monetary policy rules to be considered are evaluated based on the model's social welfare function, a second-order approximation around zero inflation of the lifetime utility function of the representative household,

$$
E_{0} \sum_{t=0}^{\infty} \beta^{t}\left[\pi_{t}^{2}+\lambda\left(x_{t}-x^{*}\right)^{2}\right]
$$

where $\lambda=\kappa / \theta$ is the weight assigned to stabilizing the output gap relative to inflation. $x^{*}$ is the target level of the output gap, which stems from monopolistic competition and distortion in the steady state. Output subsidies are assumed to offset the monopolistic distortion so that the steady state is efficient, $x^{*}=0$. As a result, in this analysis, there is no inflation bias but there is a stabilization bias due to suboptimal monetary policy and markup shocks, even if monetary policy is not constrained by the ZLB.

seller's desired markup is $\theta /(\theta-1)$. Moreover, $\alpha \in(0,1)$ is the share of firms keeping prices fixed each period, so the implied duration between price changes is $1 /(1-\alpha)$. 


\subsection{Monetary Policy}

I consider four monetary policy frameworks, namely a simple policy rule, two targeting rules, and optimal commitment policy. In each of these policy frameworks, the central bank faces a ZLB constraint and persistent errors in the measurement of economic conditions. Regardless of the ZLB constraint, the measurement errors lead to policy mistakes and therefore cause a deterioration in economic performance.

The first policy framework is an inertial Taylor rule subject to a ZLB constraint, along the lines of Taylor and Williams (2010),

$$
i_{t}=\max \left[0, \phi_{i} i_{t-1}^{u}+\left(1-\phi_{i}\right)\left(r+\phi_{\pi} \pi_{t}^{o}+\phi_{x} x_{t}^{o}\right)\right],
$$

where $\phi_{\pi}$ and $\phi_{x}$ are positive response coefficients on observed inflation, $\pi_{t}^{o}=\pi_{t}+e_{t}^{\pi}$, and the observed output gap, $x_{t}^{o}=x_{t}+e_{t}^{x}$, respectively. $e_{t}^{\pi}$ and $e_{t}^{x}$ represent noise shocks or measurement errors 8 This rule incorporates smoothing in the behavior of the interest rate, through a positive value of the coefficient $\phi_{i} \in[0,1)$. Moreover, $i_{t-1}^{u}$ denotes an unconstrained or notional interest rate, the preferred setting of the policy rate in the previous period that would occur absent the ZLB constraint. Thus, the policy rate is kept below the notional interest rate following an episode when the ZLB is a binding constraint on policy 9 This inertial Taylor rule is used for the calibration of the model (section 2.4).

The next two policy frameworks considered are targeting rules subject to a ZLB constraint. In other words, rather than following a simple policy rule, the central bank aims to stabilize a target variable by reoptimizing to the extent possible its policy decision $\left(i_{t} \geq 0\right)$ in each period. One of the targeting rules considered is strict inflation targeting,

$$
\pi_{t}^{o}=0 \text { subject to } i_{t} \geq 0
$$

\footnotetext{
${ }^{8}$ In the data, both inflation and output gaps are subject to persistent revisions (section 2.4). Thus, in the model, instead of using only one noise shock to reduce the number of state variables, both $e_{t}^{\pi}$ and $e_{t}^{x}$ are present for the policy rule to be consistent with the real-time data.

${ }^{9}$ Such an approach implies that the central bank compensates to some extent for the lost monetary stimulus due to the presence of the ZLB, even though the central bank does not commit to making up for past shortfalls from a nominallevel target.
} 
where the central bank seeks to stabilize inflation without any concern for output stability and, therefore, transfers the burden of shocks onto output. This targeting rule does not involve any inertia in the setting of monetary policy, because the current policy decision disregards past economic conditions and past misses from the target.

The other targeting rule considered in this analysis is nominalGDP-level targeting,

$$
n_{t}^{o}=0 \text { subject to } i_{t} \geq 0,
$$

where $n_{t}^{o}$ is observed nominal GDP, $n_{t}^{o}=n_{t}+e_{t}^{n}$. Specifically, $n_{t}=p_{t}+y_{t}$ is actual nominal GDP measured as the log-deviation from a trend, and $e_{t}^{n}$ is a noise shock. With this targeting rule, the central bank seeks to stabilize nominal GDP, as opposed to focusing entirely on inflation stability, which now requires the burden of shocks to be shared by inflation and output. This targeting rule involves inertia in the behavior of monetary policy because the current policy decision depends on the past price level, as $p_{t} \equiv p_{t-1}+\pi_{t}$.

Next, as a benchmark for the evaluation of these monetary policy rules, I use the optimal commitment policy. In such a policy framework, the central bank is assumed able and willing to fully commit to its policy announcements, to maximize the welfare of the representative household. In this ideal policy framework, the central bank's objective function is given by

$$
\min _{i_{t} \geq 0} E_{0} \sum_{t=0}^{\infty} \beta^{t}\left[\left(\pi_{t}^{o}\right)^{2}+\lambda\left(x_{t}^{o}\right)^{2}\right],
$$

where the central bank seeks to stabilize to the extent possible inflation and the output gap, subject to a ZLB constraint. This objective function generally differs from the social welfare function, equation (4), because the central bank faces persistent errors in the measurement of inflation and the output gap. These measurement errors cause a deterioration in economic performance, regardless of the ZLB constraint.

In these four monetary policy frameworks, the exogenous noise shocks $\left(e_{t}^{\pi}, e_{t}^{x}, e_{t}^{n}\right)$ are assumed to follow $\operatorname{AR}(1)$ stochastic processes, with first-order autocorrelation parameters $\rho_{j} \in[0,1)$ for 
$j=e^{\pi}, e^{x}, e^{n}$. Moreover, $\sigma_{\varepsilon j} \varepsilon_{j t}$ are the shock innovations buffeting the economy, which are independent across time and crosssectionally, and normally distributed with mean zero and standard deviations $\sigma_{\varepsilon j}>0$.

\subsection{Equilibrium}

At equilibrium, the policymaker chooses a policy based on a response function $\mathbf{y}\left(\mathbf{s}_{t}\right)$ and a state vector $\mathbf{s}_{t}$. The $\mathbf{s}_{t}$ includes the endogenous variables, the structural shocks, as well as the noise shocks affecting the central bank's observation of economic conditions. The corresponding expectations function is then

$$
\mathbf{E}_{t} \mathbf{y}\left(\mathbf{s}_{t+1}\right)=\int \mathbf{y}\left(\mathbf{s}_{t+1}\right) f\left(\varepsilon_{t+1}\right) d\left(\varepsilon_{t+1}\right),
$$

where $f(\cdot)$ is a probability density function of future innovations, both in the structural and noise shocks, which buffet the economy. In such a setting, an equilibrium is given by a response function and expectations function, $\mathbf{y}\left(\mathbf{s}_{t}\right)$ and $\mathbf{E}_{t} \mathbf{y}\left(\mathbf{s}_{t+1}\right)$, which satisfy the equilibrium conditions, derived in section A.1 of the appendix.

Ignoring the existence of uncertainty about the future state of the economy, the model can be solved with standard numerical methods, as done in Orphanides and Wieland (2000), Reifschneider and Williams (2000), Williams (2009), Levin et al. (2010), Coibion, Gorodnichenko, and Wieland (2012), and Guerrieri and Iacoviello (2015), among others. When the ZLB threatens, however, the mere possibility of hitting the ZLB causes expectations of a future economic downturn and therefore prompts for adding policy stimulus today, as shown by Adam and Billi (2006, 2007), Nakov (2008), and others. In this analysis, as in Billi (2011a, 2017), I use a numerical procedure that accounts for the ZLB constraint and uncertainty about the evolution of the economy 10

\subsection{Baseline Calibration}

The model economy is calibrated to revised U.S. data for recent decades, as in Billi (2017), with monetary policy described by the

\footnotetext{
${ }^{10}$ See section A.2 of the appendix for a description of the algorithm used to solve the model.
} 
inertial Taylor rule (5) that features prominently in Federal Reserve discussions. The values of the rule coefficients are taken from English, López-Salido, and Tetlow (2015), with $\phi_{\pi}$ set to $1.5, \phi_{x}$ set to $1 / 4$ (quarterly rates), and $\phi_{i}$ set to 0.85 . The rule thus accounts for smoothing in the setting of the policy interest rate.

The values of the structural parameters are also standard in the related literature. Specifically, $\beta$ is set to 0.993 , to imply $r$ equal to 3 percent annual. $\varphi$ is set to 6.2511 The implied parameters $\kappa$ and $\lambda$ are then equal to 0.024 and 0.003 (quarterly), respectively. Regarding the structural shocks, $\rho_{y^{n}, u, v}$ are set to 0.8 , to generate persistent effects on the economy. $\sigma_{y^{n}, v}$ are set to 0.8 percent (quarterly) to try to replicate respectively the volatility of output and nominal interest rates in the data, whereas $\sigma_{u}$ is set to 0.05 percent (quarterly) to match the inflation volatility in the data 12 Overall, as Billi (2017) showed, with the inertial Taylor rule and revised data, the model does a fairly good job in replicating the relevant features of recent U.S. data 13

\footnotetext{
${ }^{11} \alpha$ is set to 0.66 , so the duration between price changes $1 /(1-\alpha)$ is three quarters. $\theta$ is set to 7.66 , so the markup over marginal cost $\theta /(\theta-1)$ is 15 percent. Moreover, $\omega$ is set to 0.47 .

${ }^{12}$ The inflation rate is measured as the continuously compounded rate of change in the seasonally adjusted personal consumption expenditures chain-type price index less food and energy (source: Bureau of Economic Analysis, BEA). Output is measured as the log-deviation from trend in seasonally adjusted gross domestic product (source: BEA). The output gap is calculated as the deviation of real gross domestic product from potential, as a fraction of potential using seasonally adjusted data (source: Congressional Budget Office). And the nominal interest rate is measured as the average effective federal funds rate (source: Federal Reserve Board). The sample period used to calibrate the structural shocks is the same as in Billi (2017), 1984:Q1-2014:Q4, which ensures the results are directly comparable. Moreover, extending the sample to the latest available data does not affect the good fit of the model to the data. Real-time and revised data are obtained from archival economic data available at the Federal Reserve Bank of St. Louis, https://alfred.stlouisfed.org.

${ }^{13}$ Still, output and inflation are somewhat less persistent in the model results than in the data because this basic model, for the sake of simplicity, does not allow for structural propagation mechanisms that give rise to output and inflation inertia. As a consequence, the stylized model understates the frequency and duration of ZLB episodes. With the inertial Taylor rule and revised data, the model predicts that the policy rate hits the ZLB about 4 percent of the time, and the expected duration of a ZLB episode is about four quarters (table 2). In actuality, the federal funds rate has been near the ZLB from the end of 2008 to
} 
The calibration of the noise shocks is obtained fitting historical revisions of U.S. data, as done in Billi (2011b). Real-time estimates reflect information actually available to policymakers in each quarter, whereas revised estimates reflect information available at the end of the sample period. The difference between revised and realtime estimates is the historical revision of the data. $\left(\sigma_{\varepsilon e^{\pi}}, \sigma_{\varepsilon e^{x}}, \sigma_{\varepsilon e^{n}}\right)$ are set to match the volatility of data revisions $(0.3,1.7,1.1)$ in percent annual. $\left(\rho_{e^{\pi}}, \rho_{e^{x}}, \rho_{e^{n}}\right)$ are set to match the persistence of data revisions $(0.7,0.85,0.8) 14$ Thus, reflecting historical revisions of the data in the calibrated model, the measurement errors are notably larger and more persistent for the output gap than for nominal GDP and inflation.

\section{The Policy Evaluation}

With the calibrated model, I study the extent to which persistent measurement errors and a ZLB constraint adversely affect the performance of the two targeting rules and inertial Taylor rule, relative to the optimal commitment policy. Exploring a range of calibrations for the supply and demand shocks buffeting the economy, I show that the ranking of these monetary policy rules depends crucially on the likelihood of hitting the ZLB constraint.

\subsection{Response to Shocks}

As the first step in the evaluation of the monetary policy rules, figures 1 and 2 show the evolution of the economy when hit by the different types of structural and noise shocks in the model 15 The first figure displays responses under the optimal commitment

the end of 2015. See section 2.4 of Billi (2017) for further details of the model calibration and fit to the data.

${ }^{14}$ The half-lives of the noise shocks $\log (0.5) / \log \left(\rho_{e^{\pi}}, \rho_{e^{x}}, \rho_{e^{n}}\right)$ are equal to $(1.9,4.3,3.1)$ quarters.

${ }^{15}$ Shown are expected paths after three-standard-deviation shocks, using the baseline calibration described in section 2.4. The expected paths are obtained by averaging across 10,000 stochastic simulations. Regarding the paths shown in figure 1 , both inflation and the output gap are assumed to be mismeasured at the same time. If instead only inflation or the output gap is mismeasured, the resulting paths would be of similar shape but smaller size than the ones displayed in the figure. 


\section{Figure 1. Evolution of the Economy under Optimal Commitment or Taylor Rule}
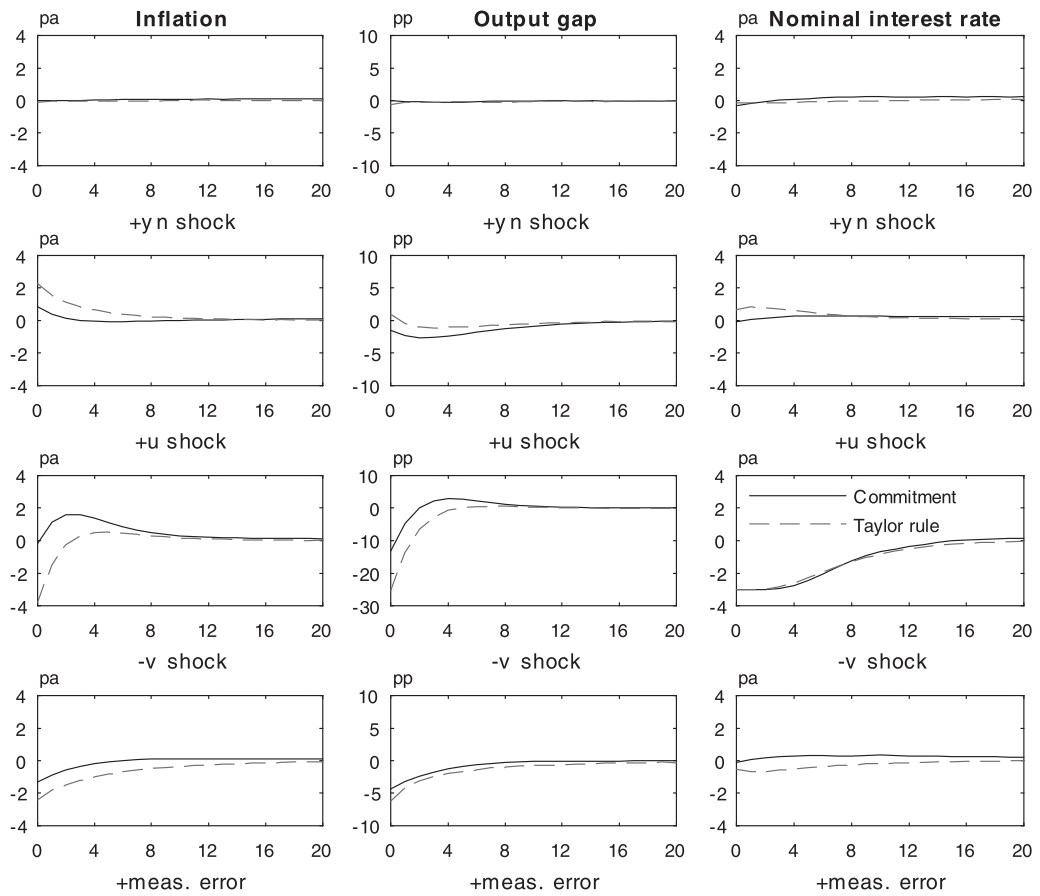

Notes: Shown are expected paths after three-standard-deviation shocks, using the baseline calibration of section 2.4. Values are expressed as percent annual (pa) or in percentage points (pp), in deviation from steady state.

policy and inertial Taylor rule, whereas the second figure displays responses under the two targeting rules. In both figures are shown the responses of inflation, the output gap, and the nominal interest rate.

Regarding the supply shocks, the top panel of the two figures shows the response to a positive technology shock, which implies slack in economic activity and downward pressure on prices. The outcome, however, depends on the monetary policy rule considered. With NGDP-level targeting (figure 2, solid line) both the output gap and inflation fall, whereas under the other three policy frameworks the economy is generally stabilized. In other words, in contrast to 


\section{Figure 2. Evolution under NGDP-Level Targeting or Strict Inflation Targeting}
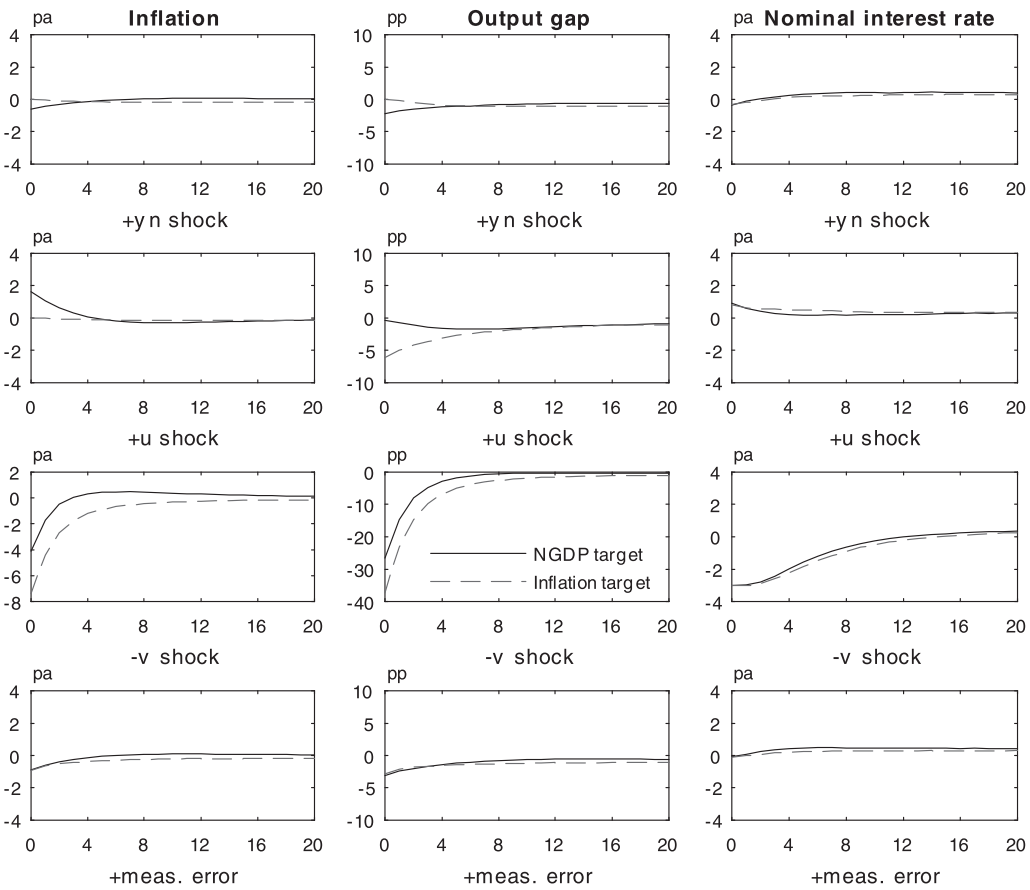

Notes: Shown are expected paths after three-standard-deviation shocks, using the baseline calibration of section 2.4. Values are expressed as percent annual (pa) or in percentage points (pp), in deviation from steady state.

the other policy frameworks, NGDP-level targeting fails to insulate the economy from technology shocks, conditional on no other shocks buffeting the economy.

The second panel shows the response to a positive markup shock, which implies upward pressure on prices and creates an inflationoutput tradeoff for monetary policy. Facing such a tradeoff, under strict inflation targeting (figure 2, dashed line), inflation is completely stabilized and output falls notably, whereas under the other three policy frameworks inflation rises and output falls. The reason is that, in contrast to the other policy frameworks, strict inflation targeting transfers the burden of markup shocks onto output. The 
other policy frameworks require instead the burden of shocks to be shared by inflation and output.

Regarding the remaining shocks in the model, the third panel of the figures shows the response to a negative demand shock, which exerts downward pressure on output and prices. Given the size of the shock, under each policy framework, the weakness of the economy prompts the central bank to cut the nominal interest rate all the way to the ZLB. During the ZLB episode, both output and inflation fall to a greater extent under strict inflation targeting, compared with the other policy frameworks considered. The reason is that, as noted earlier, strict inflation targeting does not involve any inertia in the setting of monetary policy.

Finally, the bottom panel of the figures shows the response to a positive noise shock or measurement error, which implies the central bank incorrectly assumes there is upward pressure on prices. As a consequence of such a measurement error, under each policy framework considered, the central bank mistakenly tightens the stance of monetary policy and therefore causes inflation and output to fall 16

\subsection{Economic Performance}

The ability of the central bank to stabilize the economy is adversely affected by persistent measurement errors and a ZLB constraint. To illustrate, table 1 summarizes the performance of the optimal commitment policy, in four different cases.

In the first case there is neither measurement error nor ZLB in the model, in the second there is measurement error only, in the third instead there is the ZLB only, and in the fourth there are both measurement error and ZLB. The table reports for each case the expected frequency and duration of ZLB episodes, as well as the welfare loss due to business cycles 17 As the table shows, taking into account either measurement error or the ZLB causes a deterioration in economic performance, as both inflation and output become more

\footnotetext{
${ }^{16}$ As the real interest rate (not shown) is higher, the stance of monetary policy is tightened.

${ }^{17}$ To calculate the welfare loss, first the value of the objective function (4) is obtained by averaging across 10,000 stochastic simulations, each 1,000 periods long after a burn-in period. This value is then converted into a permanent consumption loss, as explained in section A.3 of the appendix.
} 


\section{Table 1. Economic Performance under the Optimal Commitment Policy ${ }^{\mathrm{a}}$}

\begin{tabular}{|c|c|c|c|c|c|}
\hline & \multicolumn{2}{|c|}{ ZLB Episodes } & \multicolumn{3}{|c|}{ Welfare Loss ${ }^{\text {b }}$} \\
\hline & Freq. $^{\mathrm{c}}$ & Duration $^{\mathrm{d}}$ & $\pi$ & $\boldsymbol{x}$ & Tot. \\
\hline $\begin{array}{l}\text { No Measurement } \\
\text { Error, No ZLB }\end{array}$ & 0.0 & 0.0 & 0.01 & 0.02 & 0.03 \\
\hline $\begin{array}{l}\text { Measurement Error } \\
\text { Only }\end{array}$ & 0.0 & 0.0 & 0.03 & 0.03 & 0.06 \\
\hline ZLB Only & 14.5 & 2.9 & 0.03 & 0.05 & 0.08 \\
\hline $\begin{array}{l}\text { Measurement Error } \\
\text { and ZLB }\end{array}$ & 11.3 & 3.1 & 0.05 & 0.06 & 0.11 \\
\hline \multicolumn{6}{|c|}{$\begin{array}{l}\text { a Baseline calibration of section } 2.4 \text {. } \\
{ }^{b} \text { Permanent consumption loss in percentage points. } \\
{ }^{\mathrm{c}} \text { Expected percent of the time at ZLB. } \\
{ }^{\mathrm{d}} \text { Expected number of consecutive quarters at ZLB. }\end{array}$} \\
\hline
\end{tabular}

variable. However, economic performance is more severely affected by the ZLB 18

I now rank the monetary policy rules in terms of performance, relative to the optimal commitment policy, and also study whether the ranking depends on the measurement error and ZLB constraint. Table 2 summarizes the performance of each policy framework, again in the four cases. Each case is in a separate panel. In the first case, which is in the absence of measurement error and ZLB in the model, strict inflation targeting results in a smaller total welfare loss than NGDP-level targeting. With strict inflation targeting the burden of shocks is transferred onto output, but under NGDP-level targeting the shocks affect to a greater extent the volatility of inflation. Moreover, both these targeting rules perform better than the inertial Taylor rule. This ranking of the monetary policy rules is obtained also in the second case, which is in the presence of only measurement error in the model. However, because of the measurement error, strict inflation targeting is no longer able to transfer the entire burden of shocks onto output.

\footnotetext{
${ }^{18}$ The total welfare loss is 0.06 with measurement error only but rises to 0.08 with the ZLB only (table 1).
} 
Table 2. Performance of the Monetary Policy Rules ${ }^{a}$

\begin{tabular}{|c|c|c|c|c|c|}
\hline & \multicolumn{2}{|c|}{ ZLB Episodes } & \multicolumn{3}{|c|}{ Welfare Loss ${ }^{b}$} \\
\hline & Freq. $^{c}$ & Duration $^{d}$ & $\pi$ & $x$ & Tot. \\
\hline \multicolumn{6}{|c|}{ No Measurement Error, No ZLB } \\
\hline $\begin{array}{l}\text { Commitment } \\
\text { NGDP Target } \\
\text { Inflation Target } \\
\text { Taylor Rule }\end{array}$ & $\begin{array}{l}0.0 \\
0.0 \\
0.0 \\
0.0\end{array}$ & $\begin{array}{l}0.0 \\
0.0 \\
0.0 \\
0.0\end{array}$ & $\begin{array}{l}0.01 \\
0.06 \\
0.00 \\
0.21\end{array}$ & $\begin{array}{l}0.02 \\
0.01 \\
0.05 \\
0.25\end{array}$ & $\begin{array}{l}0.03 \\
0.07 \\
0.05 \\
0.46\end{array}$ \\
\hline \multicolumn{6}{|c|}{ Measurement Error Only } \\
\hline $\begin{array}{l}\text { Commitment } \\
\text { NGDP Target } \\
\text { Inflation Target } \\
\text { Taylor Rule }\end{array}$ & $\begin{array}{l}0.0 \\
0.0 \\
0.0 \\
0.0\end{array}$ & $\begin{array}{l}0.0 \\
0.0 \\
0.0 \\
0.0\end{array}$ & $\begin{array}{l}0.03 \\
0.07 \\
0.02 \\
0.31 \\
\end{array}$ & $\begin{array}{l}0.03 \\
0.02 \\
0.06 \\
0.27 \\
\end{array}$ & $\begin{array}{l}0.06 \\
0.09 \\
0.08 \\
0.58 \\
\end{array}$ \\
\hline \multicolumn{6}{|c|}{ ZLB Only } \\
\hline $\begin{array}{l}\text { Commitment } \\
\text { NGDP Target } \\
\text { Inflation Target } \\
\text { Taylor Rule }\end{array}$ & $\begin{array}{r}14.5 \\
6.2 \\
11.9 \\
4.5\end{array}$ & $\begin{array}{l}2.9 \\
1.7 \\
2.3 \\
3.4\end{array}$ & $\begin{array}{l}0.03 \\
0.09 \\
0.13 \\
0.23\end{array}$ & $\begin{array}{l}0.05 \\
0.10 \\
0.25 \\
0.29\end{array}$ & $\begin{array}{l}0.08 \\
0.19 \\
0.38 \\
0.52\end{array}$ \\
\hline \multicolumn{6}{|c|}{ Measurement Error and ZLB } \\
\hline $\begin{array}{l}\text { Commitment } \\
\text { NGDP Target } \\
\text { Inflation Target } \\
\text { Taylor Rule }\end{array}$ & $\begin{array}{r}11.3 \\
6.3 \\
11.6 \\
3.8\end{array}$ & $\begin{array}{l}3.1 \\
1.7 \\
2.3 \\
3.4\end{array}$ & $\begin{array}{l}0.05 \\
0.11 \\
0.15 \\
0.33\end{array}$ & $\begin{array}{l}0.06 \\
0.11 \\
0.26 \\
0.32\end{array}$ & $\begin{array}{l}0.11 \\
0.22 \\
0.41 \\
0.65\end{array}$ \\
\hline $\begin{array}{l}{ }^{\mathrm{a}} \text { Baseline calibrati } \\
{ }^{\mathrm{b}} \text { Permanent consu } \\
{ }^{\mathrm{c}} \text { Expected percent } \\
{ }^{\mathrm{d}} \text { Expected number }\end{array}$ & $\begin{array}{l}\text { section } 2 \\
\text { n loss in } \\
\text { e time at } \\
\text { onsecutive }\end{array}$ & $\begin{array}{l}\text { entage points. } \\
\text { arters at ZLB. }\end{array}$ & & & \\
\hline
\end{tabular}

Turning to the third case, which is in the presence of the ZLB only, NGDP-level targeting now results in a smaller total welfare loss than strict inflation targeting. Moreover, due to the ZLB, strict inflation targeting is unable to transfer the entire burden of shocks onto output. The reason for this change in the ranking among the targeting rules is that, as noted earlier, strict inflation targeting does not 
involve any inertia in the setting of monetary policy, whereas under NGDP-level targeting the current policy decision depends on the past price level. Nevertheless, both targeting rules still perform better than the inertial Taylor rule. This ranking of the monetary policy rules remains the same when turning to the fourth case, which is in the presence of both measurement error and ZLB in the model 19

In summary, the implications of measurement error and a ZLB constraint for the ranking of the monetary policy rules are twofold. On the one hand, taking into account measurement error does not affect the ranking of the rules considered. On the other hand, taking into account the ZLB constraint inverts the ranking of the targeting rules, as NGDP-level targeting provides inertia in the setting of monetary policy and therefore outperforms strict inflation targeting when in the presence of the ZLB constraint.

\subsection{Alternate Calibrations}

The ranking of the monetary policy rules is affected by the likelihood of hitting the ZLB constraint. To illustrate, I modify the calibration of the supply and demand shocks, in the presence of both measurement error and ZLB in the model 20

I start by increasing the role of supply shocks, with table 3 summarizing the resulting performance of the policy frameworks. First, technology shocks are assumed to be substantially larger or more persistent than in the baseline calibration. However, as a comparison with the bottom panel of table 2 shows, this more prominent role assigned to technology shocks does not affect the volatility of the output gap and inflation and therefore leaves the policy ranking unchanged. In other words, after accounting for measurement error and ZLB, all four policy frameworks manage to insulate the economy from these bigger technology shocks. Second, markup shocks

\footnotetext{
${ }^{19}$ The result that with the baseline calibration of the model the two targeting rules perform better than the inertial Taylor rule should not be viewed as an argument against the use of simple policy rules, as this ranking depends on the calibration of the Taylor rule. For an illustration of this point, see section A.4 of the appendix.

${ }^{20}$ In tables 3 and 4 , each type of structural shock is modified, either raising its standard deviation by 25 percent or increasing its persistence from 0.8 to 0.9 , relative to the baseline calibration. Also shown in table $4, r$ is lowered from 3 to 2 percent annual, with $\beta$ raised accordingly from 0.993 to 0.995 .
} 


\section{Table 3. Performance of the Rules, Alternate Calibrations $^{\mathrm{a}}$}

\begin{tabular}{|c|c|c|c|c|c|}
\hline & \multicolumn{2}{|c|}{ ZLB Episodes } & \multicolumn{3}{|c|}{ Welfare Loss ${ }^{\mathbf{b}}$} \\
\hline & Freq. ${ }^{\text {c }}$ & Duration $^{d}$ & $\pi$ & $x$ & Tot. \\
\hline \multicolumn{6}{|c|}{ Larger Technology Shocks $\left(\sigma_{y^{n}}=1\right)$} \\
\hline Commitment & 11.1 & 3.1 & 0.05 & 0.06 & 0.11 \\
\hline NGDP Target & 6.0 & 1.7 & 0.11 & 0.11 & 0.22 \\
\hline Inflation Target & 11.4 & 2.3 & 0.15 & 0.26 & 0.41 \\
\hline Taylor Rule & 3.7 & 3.3 & 0.33 & 0.32 & 0.65 \\
\hline \multicolumn{6}{|c|}{ More Persistent Technology Shocks $\left(\rho_{y^{n}}=0.9\right)$} \\
\hline Commitment & 11.4 & 3.0 & 0.05 & 0.06 & 0.11 \\
\hline NGDP Target & 5.9 & 1.7 & 0.11 & 0.11 & 0.22 \\
\hline Inflation Target & 12.4 & 2.4 & 0.15 & 0.26 & 0.41 \\
\hline Taylor Rule & 3.8 & 3.4 & 0.33 & 0.32 & 0.65 \\
\hline \multicolumn{6}{|c|}{ Larger Markup Shocks $\left(\sigma_{u}=0.0625\right)$} \\
\hline Commitment & 11.3 & 3.1 & 0.06 & 0.07 & 0.13 \\
\hline NGDP Target & 6.1 & 1.7 & 0.13 & 0.11 & 0.24 \\
\hline Inflation Target & 11.2 & 2.3 & 0.16 & 0.29 & 0.45 \\
\hline Taylor Rule & 3.7 & 3.3 & 0.39 & 0.33 & 0.72 \\
\hline \multicolumn{6}{|c|}{ More Persistent Markup Shocks $\left(\rho_{u}=0.9\right)$} \\
\hline Commitment & 11.2 & 3.1 & 0.05 & 0.07 & 0.12 \\
\hline NGDP Target & 5.6 & 1.7 & 0.12 & 0.12 & 0.24 \\
\hline Inflation Target & 12.8 & 2.4 & 0.15 & 0.26 & 0.41 \\
\hline Taylor Rule & 4.6 & 3.6 & 0.40 & 0.34 & 0.74 \\
\hline \multicolumn{6}{|c|}{$\begin{array}{l}{ }^{a} \text { With measurement error and ZLB in the model. } \\
{ }^{\mathrm{b}} \text { Permanent consumption loss in percentage points. } \\
{ }^{\mathrm{c} E x p e c t e d ~ p e r c e n t ~ o f ~ t h e ~ t i m e ~ a t ~ Z L B . ~} \\
{ }^{\mathrm{d}} \text { Expected number of consecutive quarters at ZLB. }\end{array}$} \\
\hline
\end{tabular}

are assumed to be substantially larger or more persistent than in the baseline calibration. This more prominent role given to markup shocks generally leads to higher volatility of the output gap and inflation, but the policy ranking is still unchanged. 
Table 4. Alternate Calibrations ${ }^{\mathrm{a}}$

\begin{tabular}{|c|c|c|c|c|c|}
\hline & \multicolumn{2}{|c|}{ ZLB Episodes } & \multicolumn{3}{|c|}{ Welfare Loss ${ }^{\text {b }}$} \\
\hline & Freq. ${ }^{\mathrm{c}}$ & Duration $^{\mathrm{d}}$ & $\pi$ & $x$ & Tot. \\
\hline \multicolumn{6}{|c|}{ Larger Demand Shocks $\left(\sigma_{v}=1\right)$} \\
\hline Commitment & 17.9 & 3.8 & 0.10 & 0.10 & 0.20 \\
\hline NGDP Target & 10.0 & 2.0 & 0.16 & 0.25 & 0.41 \\
\hline Inflation Target & 16.5 & 2.7 & 0.52 & 0.71 & 1.23 \\
\hline Taylor Rule & 7.6 & 3.9 & 0.42 & 0.55 & 0.97 \\
\hline \multicolumn{6}{|c|}{ More Persistent Demand Shocks $\left(\rho_{v}=0.9\right)$} \\
\hline Commitment & 13.2 & 5.4 & 0.10 & 0.06 & 0.16 \\
\hline NGDP Target & 6.4 & 2.4 & 0.18 & 0.21 & 0.39 \\
\hline Inflation Target & 12.1 & 3.5 & 5.03 & 3.60 & 8.63 \\
\hline Taylor Rule & 5.7 & 3.7 & 0.37 & 0.42 & 0.79 \\
\hline \multicolumn{6}{|c|}{ Lower Steady-State Interest Rate $(r=0.5)$} \\
\hline Commitment & 19.7 & 4.1 & 0.10 & 0.09 & 0.19 \\
\hline NGDP Target & 10.6 & 2.0 & 0.16 & 0.24 & 0.40 \\
\hline Inflation Target & 19.2 & 2.9 & 0.66 & 0.80 & 1.46 \\
\hline Taylor Rule & 10.4 & 4.3 & 0.38 & 0.42 & 0.80 \\
\hline
\end{tabular}

Next, I assign instead a more prominent role to demand shocks, with table 4 summarizing the resulting performance of the policy frameworks. First, demand shocks are assumed to be substantially larger or more persistent than in the baseline calibration. As a comparison with the bottom panel of table 2 shows, under each policy framework, inflation and output generally become more variable. But this deterioration in economic performance is substantially larger under strict inflation targeting, compared with the other policy frameworks. The reason is that, as noted earlier, strict inflation targeting does not involve any inertia in the setting of monetary policy. As a result, strict inflation targeting now results in a larger total welfare loss than the other policy rules. Finally, the steady-state 
interest rate is substantially lower than in the baseline calibration, which implies that monetary policy is more severely constrained by the ZLB. Again strict inflation targeting is outperformed by the other policy rules.

In summary, these changes to the calibration imply the following for the ranking of the monetary policy rules. Even if the economy is hit by supply shocks that are substantially larger or more persistent than in the baseline calibration, the policy ranking is not affected. But if the role of demand shocks is more prominent than in the baseline calibration, and therefore monetary policy is more severely constrained by the ZLB, then strict inflation targeting is outperformed by the other policy rules considered in this analysis.

\section{Concluding Remarks}

Policymakers often use the output gap to guide monetary policy, even though inflation and nominal GDP are measured more accurately in real time than the output gap. Employing a small New Keynesian model, which offers a clear illustration of the tradeoffs faced by a central bank during ZLB episodes, this article compares the performance of monetary policy rules that are robust to persistent errors in the measurement of economic conditions.

The analysis shows that, in the absence of the ZLB, the central bank should focus on stabilizing inflation rather than nominal GDP. But when the ZLB is present, a policy that seeks to stabilize the level of nominal GDP improves substantially the tradeoffs faced by the central bank. Still, the analysis is conducted in a stylized model that does not include an explicit role for balance sheet policies, nor monetary policies based on monetary aggregates that have the potential to circumvent the ZLB constraint. See Belongia and Ireland (2017) for a discussion. It would be interesting to extend the analysis to include such features in future research.

\section{Appendix}

This appendix is organized in four sections. Section A.1 derives the equilibrium conditions of the model. Section A.2 describes the numerical procedure used to solve the model. Section A.3 explains 
the calculation of the permanent consumption loss. Section A.4 provides additional results about the evaluation of the inertial Taylor rule relative to the baseline calibration of the model.

\section{A.1 Equilibrium Conditions}

I first derive the equilibrium conditions and then summarize them in a table.

Optimal Commitment Policy. The problem can be written as

$$
\begin{aligned}
V\left(\mathbf{s}_{t}\right)= & \min \left[\left(\pi_{t}+e_{t}^{\pi}\right)^{2}+\lambda\left(y_{t}-y_{t}^{n}+e_{t}^{x}\right)^{2}+\beta E_{t} V\left(\mathbf{s}_{t+1}\right)\right] \\
& \text { subject to (1), (3) and } i_{t} \geq 0 .
\end{aligned}
$$

Write the period Lagrangian:

$$
\begin{aligned}
L_{t}= & \left(\pi_{t}+e_{t}^{\pi}\right)^{2}+\lambda\left(y_{t}-y_{t}^{n}+e_{t}^{x}\right)^{2}+\beta E_{t} V\left(\mathbf{s}_{t+1}\right) \\
& +m_{1 t}\left[\pi_{t}-\kappa\left(y_{t}-y_{t}^{n}\right)-u_{t}\right]-m_{1 t-1} \pi_{t} \\
& +m_{2 t}\left[y_{t}+\varphi\left(i_{t}-r-v_{t}\right)\right]-\beta^{-1} m_{2 t-1}\left(y_{t}+\varphi \pi_{t}\right) .
\end{aligned}
$$

The Kuhn-Tucker conditions are

$$
\begin{aligned}
& 0=\partial L_{t} / \partial \pi_{t}=2\left(\pi_{t}+e_{t}^{\pi}\right)+m_{1 t}-m_{1 t-1}-\beta^{-1} \varphi m_{2 t-1} \\
& 0=\partial L_{t} / \partial y_{t}=2 \lambda\left(y_{t}-y_{t}^{n}+e_{t}^{x}\right)-\kappa m_{1 t}+m_{2 t}-\beta^{-1} m_{2 t-1} \\
& 0=\partial L_{t} / \partial i_{t} \cdot i_{t}=\varphi m_{2 t} \cdot i_{t}, \quad m_{2 t} \geq 0, \quad i_{t} \geq 0 .
\end{aligned}
$$

The equilibrium conditions are summarized in table A.1.

\section{A.2 Numerical Procedure}

I find a numerical solution, as in Billi (2011a, 2017), as a fixed point in the equilibrium conditions. To do so, the state vector is discretized into a grid of interpolation nodes, with a support of \pm 4 standard deviations for each state variable, which is large enough to avoid erroneous extrapolation. If the state is not on this grid, the response function is evaluated with multilinear interpolation. The approximation residuals are evaluated at a finer grid, to ensure the accuracy of the results. The expectations function is evaluated 


\section{Table A.1. Summary of Equilibrium Conditions}

\begin{tabular}{|l|c|c|}
\hline Policy & $\begin{array}{c}\text { Equilibrium } \\
\text { Conditions }\end{array}$ & State Vector s $\mathbf{s}_{t}$ \\
\hline Optimal & $(1),(3)$, and (A.1)-(A.3) & $\left(y_{t}^{n}, u_{t}, v_{t}, e_{t}^{\pi}, e_{t}^{x}, m_{1 t-1}, m_{2 t-1}\right)$ \\
Commitment & $(1),(3)$, and (5) & $\left(y_{t}^{n}, u_{t}, v_{t}, e_{t}^{\pi}, e_{t}^{x}, i_{t-1}^{u}\right)$ \\
$\begin{array}{c}\text { Inertial Taylor } \\
\text { Rule }\end{array}$ & $\left(y_{t}^{n}, u_{t}, v_{t}, e_{t}^{\pi}\right)$ \\
Strict Inflation & $(1),(3)$, and (6) \\
Target & $(1)-(3)$ and (7) & $\left(y_{t}^{n}, u_{t}, v_{t}, e_{t}^{n}, p_{t-1}\right)$ \\
NGDP-Level & \\
Target & & \\
\hline
\end{tabular}

with Gaussian-Hermite quadrature. The initial guess is the linearized solution that ignores the ZLB constraint. This numerical procedure is coded in MATLAB. Replication files are available from the author upon request.

\section{A.3 Permanent Consumption Loss}

I obtain the permanent consumption loss as in Billi (2011a, 2017). The expected lifetime utility of the representative household is validly approximated by

$$
E_{0} \sum_{t=0}^{\infty} \beta^{t} U_{t}=\frac{U_{c} \bar{C}}{2} \frac{\alpha \theta(1+\omega \theta)}{(1-\alpha)(1-\alpha \beta)} L,
$$

where $\bar{C}$ is steady-state consumption; $U_{c}>0$ is steady-state marginal utility of consumption; and $L \geq 0$ is the value of objective function (4).

At the same time, a steady-state consumption loss of $\mu \geq 0$ causes a utility loss of

$$
E_{0} \sum_{t=0}^{\infty} \beta^{t} U_{c} \bar{C} \mu=\frac{1}{1-\beta} U_{c} \bar{C} \mu .
$$

Equating the right sides of (A.4) and (A.5) gives

$$
\mu=\frac{1-\beta}{2} \frac{\alpha \theta(1+\omega \theta)}{(1-\alpha)(1-\alpha \beta)} L .
$$


Table A.2. Performance of Inertial Taylor Rule

\begin{tabular}{|c|c|c|c|c|c|c|}
\hline \multirow[b]{2}{*}{$\emptyset_{x}$} & \multirow[b]{2}{*}{$\emptyset_{\pi}$} & \multicolumn{2}{|c|}{ ZLB Episodes } & \multicolumn{3}{|c|}{ Welfare Loss ${ }^{a}$} \\
\hline & & Freq. $^{\mathrm{b}}$ & Duration $^{c}$ & $\pi$ & $x$ & Tot. \\
\hline 0.250 & 1.5 & 3.8 & 3.4 & 0.33 & 0.32 & 0.65 \\
\hline 0.125 & 1.5 & 2.6 & 3.1 & 0.40 & 0.53 & 0.93 \\
\hline 0.250 & 5.0 & 5.7 & 3.6 & 0.14 & 0.24 & 0.38 \\
\hline
\end{tabular}

\section{A.4 Evaluation of the Taylor Rule}

With measurement error and ZLB in the model, table A.2 shows the performance of the inertial Taylor rule (5) for alternate values of its response coefficients compared with the baseline calibration of the model. The first line is the model outcome using the baseline calibration (that is, the same outcome as in the bottom panel of table 2).

This table illustrates two results about the response coefficients. First, a weaker response to the observed output gap than in the baseline causes a deterioration in economic performance, as inflation and output become more variable. The reason is that the weaker response to the output gap worsens the inflation-output tradeoff faced by the central bank. If $\phi_{x}$ is lowered from 0.25 to 0.125 , the total welfare loss under the inertial Taylor rule increases from 0.65 to 0.93 . Thus, even though the output gap is subject to large and persistent revisions, it is desirable for monetary policy to respond to a certain extent to the output gap.

Second, as the table also shows, a stronger response to observed inflation results in an improvement in economic performance. The inertial Taylor rule can even outperform strict inflation targeting but still performs worse than NGDP-level targeting. If $\phi_{\pi}$ is raised from 1.5 to 5 , the total welfare loss under the inertial Taylor rule falls from 0.65 to 0.38 . Instead under the targeting rules, the total welfare loss is 0.41 with strict inflation targeting but only 0.22 with NGDP-level targeting (bottom panel of table 2). Values of $\phi_{\pi}$ above 5 are not considered because they are typically viewed as impractically high. 


\section{References}

Adam, K., and R. M. Billi. 2006. "Optimal Monetary Policy under Commitment with a Zero Bound on Nominal Interest Rates." Journal of Money, Credit and Banking 38 (7): 1877-1905. . 2007. "Discretionary Monetary Policy and the Zero Lower Bound on Nominal Interest Rates." Journal of Monetary Economics 54 (3): 728-52.

Aoki, K. 2003. "On the Optimal Monetary Policy Response to Noisy Indicators." Journal of Monetary Economics 50 (3): 501-23.

- 2006. "Optimal Commitment Policy under Noisy Information." Journal of Economic Dynamics and Control 30 (1): 81-109.

Bean, C. R. 1983. "Targeting Nominal Income: An Appraisal." Economic Journal 93 (372): 806-19.

Belongia, M. T., and P. N. Ireland. 2017. "Circumventing the Zero Lower Bound with Monetary Policy Rules Based on Money." Journal of Macroeconomics 54 (Part A): 42-58.

Billi, R. M. 2011a. "Optimal Inflation for the U.S. Economy." American Economic Journal: Macroeconomics 3 (3): 29-52.

. 2011b. "Output Gaps and Monetary Policy at Low Interest Rates." Economic Review (Federal Reserve Bank of Kansas City) 96 (First Quarter): 5-29.

. 2017. "A Note on Nominal GDP Targeting and the Zero Lower Bound." Macroeconomic Dynamics 21 (8): 2138-57.

Boehm, C. E., and C. L. House. 2014. "Optimal Taylor Rules in New Keynesian Models." NBER Working Paper No. 20237.

Clark, T. E. 1994. "Nominal GDP Targeting Rules: Can They Stabilize the Economy?" Economic Review (Federal Reserve Bank of Kansas City) 79 (Third Quarter): 11-25.

Coibion, O., Y. Gorodnichenko, and J. Wieland. 2012. "The Optimal Inflation Rate in New Keynesian Models: Should Central Banks Raise Their Inflation Targets in Light of the Zero Lower Bound?" Review of Economic Studies 79 (4): 1371-1406.

Ehrmann, M., and F. Smets. 2003. "Uncertain Potential Output: Implications for Monetary Policy." Journal of Economic Dynamics and Control 27 (9): 1611-38.

English, W. B., J. D. López-Salido, and R. J. Tetlow. 2015. "The Federal Reserve's Framework for Monetary Policy: Recent 
Changes and New Questions." IMF Economic Review 63 (1): 22-70.

Frankel, J. 2013. "Nominal-GDP Targets, without Losing the Inflation Anchor." In Is Inflation Targeting Dead? Central Banking After the Crisis, ed. L. Reichlin, and R. Baldwin, 90-94. London: CEPR, VoxEU.org.

Garín, J., R. Lester, and E. Sims. 2016. "On the Desirability of Nominal GDP Targeting." Journal of Economic Dynamics and Control 69 (August): 21-44.

Guerrieri, L., and M. Iacoviello. 2015. "OccBin: A Toolkit for Solving Dynamic Models with Occasionally Binding Constraints Easily." Journal of Monetary Economics 70 (March): 22-38.

Gust, C. J., B. K. Johannsen, and J. D. López-Salido. 2017. "Monetary Policy, Incomplete Information, and the Zero Lower Bound." IMF Economic Review 65 (1): 37-70.

Hall, R. E., and N. G. Mankiw. 1994. "Nominal Income Targeting." In Monetary Policy, ed. N. G. Mankiw, 71-93 (chapter 2). Chicago and London: University of Chicago Press.

Hatzius, J., and S. J. Stehn. 2011. "The Case for a Nominal GDP Level Target." US Economics Analyst (Goldman Sachs) 11/41, October 14 .

- 2013. "A Nominal GDP Level Target in All but Name." US Economics Analyst (Goldman Sachs) 13/03, January 20.

Jensen, H. 2002. "Targeting Nominal Income Growth or Inflation?" American Economic Review 92 (4): 928-56.

Levin, A., D. López-Salido, E. Nelson, and T. Yun. 2010. "Limitations on the Effectiveness of Forward Guidance at the Zero Lower Bound." International Journal of Central Banking 6 (1, March): 143-89.

McCallum, B. T. 1988. "Robustness Properties of a Rule for Monetary Policy." Carnegie-Rochester Conference Series on Public Policy 29 (1): 173-204.

Meade, J. E. 1978. "The Meaning of 'Internal Balance'." Economic Journal 88 (351): 423-35.

Nakov, A. 2008. "Optimal and Simple Monetary Policy Rules with Zero Floor on the Nominal Interest Rate." International Journal of Central Banking 4 (2, June): 73-127.

Orphanides, A. 2001. "Monetary Policy Rules Based on Real-Time Data." American Economic Review 91 (4): 964-85. 
. 2003. "Monetary Policy Evaluation with Noisy Information." Journal of Monetary Economics 50 (3): 605-31.

Orphanides, A., R. D. Porter, D. Reifschneider, R. Tetlow, and F. Finan. 2000. "Errors in the Measurement of the Output Gap and the Design of Monetary Policy." Journal of Economics and Business 52 (1-2): 117-41.

Orphanides, A., and S. van Norden. 2002. "The Unreliability of Output-Gap Estimates in Real Time." Review of Economics and Statistics 84 (4): 596-83.

Orphanides, A., and V. Wieland. 2000. "Efficient Monetary Policy Design Near Price Stability." Journal of the Japanese and International Economies 14 (4): 327-65.

Reifschneider, D., and J. C. Williams. 2000. "Three Lessons for Monetary Policy in a Low-Inflation Era." Journal of Money, Credit and Banking 32 (4): 936-66.

Rudebusch, G. D. 2002. "Assessing Nominal Income Rules for Monetary Policy with Model and Data Uncertainty." Economic Journal 112 (479): 402-32.

Smets, F. 2002. "Output Gap Uncertainty: Does It Matter for the Taylor Rule?" Empirical Economics 27 (1): 113-29.

Sumner, S. B. 2011. "Re-Targeting the Fed." National Affairs 41 (Fall): 79-96.

- 2014. "Nominal GDP Targeting: A Simple Rule to Improve Fed Performance." Cato Journal 34 (2): 315-37.

Svensson, L. E. O. 2010. "Monetary Policy and Financial Markets at the Effective Lower Bound." Journal of Money, Credit and Banking 42 (s1): 229-42.

Svensson, L. E. O., and M. Woodford. 2003. "Indicator Variables for Optimal Policy." Journal of Monetary Economics 50 (3): 691-720.

- 2004. "Indicator Variables for Optimal Policy under Asymmetric Information." Journal of Economic Dynamics and Control 28 (4): 661-90.

Taylor, J. B. 1985. "What Would Nominal GNP Targeting Do to the Business Cycle?" Carnegie-Rochester Conference Series on Public Policy 22 (1): 61-84.

Taylor, J. B., and J. C. Williams. 2010. "Simple and Robust Rules for Monetary Policy." In Handbook of Monetary Economics, Vol. 
3, ed. B. M. Friedman, and M. Woodford, 829-59 (chapter 15). Amsterdam: Elsevier B.V.

Tobin, J. 1980. "Stabilization Policy Ten Years After." Brookings Papers on Economic Activity 11 (1): 19-90.

Walsh, C. E. 2003. "Speed Limit Policies: The Output Gap and Optimal Monetary Policy." American Economic Review 93 (1): $265-78$.

West, K. D. 1986. "Targeting Nominal Income: A Note." Economic Journal 96 (384): 1077-83.

Williams, J. C. 2009. "Heeding Daedalus: Optimal Inflation and the Zero Lower Bound." Brookings Papers on Economic Activity 40 (2): 1-45.

Woodford, M. 2010. "Optimal Monetary Stabilization Policy." In Handbook of Monetary Economics, Vol. 3, ed. B. M. Friedman and M. Woodford, 723-828 (chapter 14). Amsterdam: Elsevier B.V.

- 2012. "Methods of Policy Accommodation at the InterestRate Lower Bound." In The Changing Policy Landscape. Proceedings of the 2012 Economic Policy Symposium sponsored by the Federal Reserve Bank of Kansas City, held in Jackson Hole, Wyoming, August 30-September 1.

- 2013. "Inflation Targeting: Fix It, Don't Scrap It." In Is inflation Targeting Dead? Central Banking After the Crisis, ed. L. Reichlin and R. Baldwin, 74-89. London: CEPR, VoxEU.org. 